\title{
State-of-the-Art of Mini Grids for Rural Electrification in West Africa
}

\author{
Fernando Antonanzas-Torres ${ }^{1, * \mathbb{D}}$, Javier Antonanzas ${ }^{2}$ and Julio Blanco-Fernandez ${ }^{1}$ (D) \\ 1 Department of Mechanical Engineering, University of La Rioja, 26004 Logroño, Spain; julio.blanco@unirioja.es \\ 2 Department of Mechanical Engineering, Colorado State University, 430 University Ave, \\ Fort Collins, CO 80523, USA; antonanzas.javier@gmail.com \\ * Correspondence: antonanzas.fernando@gmail.com
}

Citation: Antonanzas-Torres, F.; Antonanzas, J.; Blanco-Fernandez, J State-of-the-Art of Mini Grids for Rural Electrification in West Africa. Energies 2021, 14, 990. https:// doi.org/10.3390/en14040990

Academic Editor: Dimitrios Katsaprakakis

Received: 8 January 2021

Accepted: 9 February 2021

Published: 13 February 2021

Publisher's Note: MDPI stays neutral with regard to jurisdictional claims in published maps and institutional affiliations.

Copyright: (c) 2021 by the authors. Licensee MDPI, Basel, Switzerland. This article is an open access article distributed under the terms and conditions of the Creative Commons Attribution (CC BY) license (https:// creativecommons.org/licenses/by/ $4.0 /)$.

\begin{abstract}
The current electrification status in West African countries presents rural electrification rates below $40 \%$, national grid losses above 39\% with frequent disruptions, and electricity prices averaging $\$ 0.35 / \mathrm{kWh}$, up to national values of $\$ 0.66 / \mathrm{kWh}$. With this, off-grid systems have gained great attention during the last decade as energy solutions; especially solar home systems (SHS) and mini grids. Nowadays, 385 mini grids with a power of near $30 \mathrm{MW}$ are operating in West Africa, with 95\% based on PV. Since 2019, result-based tenders with international aid funding-more effective than previous competitive tenders-seek to install at least 317 new mini grids in Togo, 250 in Nigeria, 100 in Burkina Faso, and two in Mali. Besides, the market for mini-grid energy access start-ups grew from \$19 million in 2013 to \$339 million in 2018. Despite this recent development in West Africa, research and data for mini grids in this region is scarce, and it is mostly approached from the technological side, with a striking lack of information regarding the social impact. This work tries to describe the present status of research and current operating installations, as well as the main challenges for future development of off grid mini grids in West Africa, which pose as the missing link between SHS and grid extension.
\end{abstract}

Keywords: mini grid; rural electrification; off-grid energy; West Africa

\section{Introduction}

Nowadays, the global electrification rate is $\sim 90 \%$, which implies that still around 789 million people lack access to electricity according to the latest data available in 2018, of which $85 \%$ live in rural areas [1]. Since 2010, 1034 million people have gained access to electricity, when the coverage was $83 \%$. Access to electricity is unequal among regions, with the lowest electrification rates being found in Sub-Saharan Africa (SSA), where 573 million people lack access to electricity. The significant increase in the energy demand in SSA (due to population and industrialization growth) implies a wide range of challenges in terms of sustainability: increasing electrification rate, increasing installed capacity, lowering energy prices, reinforcing current electricity lines, and improving availability and quality of service [2].

The fulfillment of the United Nations 2030 Agenda for the Sustainable Development Goal 7 (SDG 7), to "ensure access to affordable, reliable, sustainable and modern energy for all for 2030" [3] is endangered due to the estimated 650 million people to lack electricity in 2030, of which $85 \%$ would be found in SSA [1]. Regarding the SDG 7.1 related to a "universal access to an affordable, modern, and reliable energy service", the latest data show that electricity is unaffordable in terms of consumption for about 285 million people and in terms of the connection cost for 400 million, with a quality of service negatively affected with frequent disruptions, mainly in SSA [4]. In this line, off-grid systems for self-generation such as solar home systems (SHS) and mini grids present as alternatives to national grid extension, while third-generation mini grids serve as back-up systems to improve the quality of electricity service in sites with previous grid connection, all expected 
to have high relevance in SSA [5]. Grid extension to rural areas with scattered populations is frequently postponed by governments due to technical and economic factors [6]. This has opened the path in electricity-demanding areas for communities, hybrid joint ventures (private, community, government, and non-governmental organizations (NGOs)) and private companies to invest in mini grids [7]. The striking fall in the levelized cost of PV electricity (LCOE) in the last decade [8] and the novel mechanisms of payment and monitoring $[9,10]$ must be considered as fundamental factors for this change. Still, different studies reveal that most mini grid projects deployed in SSA are financed or partially financed by international organizations for development, NGOs, or cooperation agencies of developed countries [2].

Current off-grid electrification is estimated for 136 million people with at least "Tier 1 " globally—the energy of at least a solar home system of 11-50 W [11]—through either standalone individual systems or mini grids, $85 \%$ of these off-grid systems are based on photovoltaics (PV) [1,12]. While off-grid alone systems provide electricity to a single user, typically diesel generators and solar home systems (SHS), the latter with a power of 50-500 W, mini grids provide electricity to several users through a distribution grid with metering mechanisms. Mini grids can operate in isolation from, or connection to, the national grid with capacities of micro size (1-10 kW) and larger size (from $10 \mathrm{~kW}$ to $10 \mathrm{MW}$ ) [13,14]. A wide range of mini grid designs have been described depending on the type of generation technology (PV, diesel generator, wind, hydro, or biomass), battery technology (lead-acid and Li-ion batteries) and hybridization (fossil-fuel, wind, or hydro) [15-17].

Between pure off-grid systems and pure on-grid systems there is a gray line in which third-generation mini grids aim to increase the power of on-grid remote towns and cities that require more electricity or in which the grid quality of service is low. In this line, the contradiction in the political discourse that associates mini grids with rural electrification is common, but political effort is put into large-scale third-generation mini grids for injecting into the grid in urban areas or for mining applications, i.e., in Ghana [18]. The fact that the population in these towns is denser and the economic activity presumably higher makes these mini grids more interesting for investors than village size off grid mini grids. Predictable cash flows, monitoring and accessibility to the mini grid, previous tradition of customers to pay for electricity, and a likely easier maintenance of the system make thirdgeneration mini grids a totally different business than mini grids for rural electrification. However, it is noteworthy than under the mini grid discourse, it is frequently associated with rural electrification and transformation for sustainable development, which makes easier the access to donors and international support $[6,13]$.

Electrification in West Africa, a region with 15 countries with some of the world's lowest electrification rates, has gained international attention in the last decade regarding SDG7. Different sources of international funding channeled through national tenders have achieved the installation of 385 mini grids and the launch of tenders and projected plans (2019-2020) for a massive mini grid development in West Africa. In this line, the European Green Deal, a UE plan for economic recovery post-COVID-19, has assigned 1bn euro for 2021-2027, considering as one of the main objectives "accelerating the clean energy transition and energy access in partnership with Africa", which supports the importance and interest that mini grids are receiving from the international community [19]. The interest and novelty of this field and the lack of academic reviews addressing the state-ofthe-art of mini grids regarding installation and research in West Africa have motivated this study. It has three major objectives: to present the current status of electrification with mini grids in West Africa, to show which is the state of the art in terms of academic research, and to highlight some of the major challenges for future mini grid deployment.

The structure of the text is straightforward: Section 2 addresses the current status of mini grid electrification in the region; Section 3 summarizes the review of the state of the art in academic research; Section 4 shows and comments the challenges for mini grid 
deployment; and finally Sections 5 and 6 suggest some future research lines, summarize the findings, and provide some recommendations to ease the extension of this energy source.

\section{Current Electrification in West Africa}

The 15 states integrated in this study are the countries belonging to the Economic Community of West African States (ECOWAS): Benin, Burkina Faso, Cape Verde, Cote d'Ivoire, Gambia, Ghana, Guinea, Guinea Bissau, Liberia, Mali, Niger, Nigeria, Senegal, Sierra Leone, and Togo. The fulfillment of SDG7 in this region is extremely challenging due to an electrification rate below 50\% in 2019 (more than 170 million without access to electricity) [20] and high electricity prices mainly depending on the burning of diesel and heavy fuel, which represents the majority of the supply in eight of these countries [21].

Table 1 depicts country indicators regarding access to electricity. Urban and rural electrification rates within this region averaged $70.0 \%$ and $27 \%$, respectively. Only Cape Verde, Cote d'Ivoire, Ghana, and Senegal had rural electrification rates above $30 \%$, while Burkina Faso, Guinea-Bissau, Liberia, Niger, and Sierra Leone covered less than 7\% [20].

Table 1. Country information. National electrification rate (El. Rate), urban electrification (Urban El.), rural electrification (Rural El.), and population without electricity (PWE) in million people for 2019; data reproduced with permission from [20]. On grid charged electricity, data reproduced with permission from [22]. On grid scheme, where IPP stands for independent power producer, G generation, T transmission, D distribution, VIU vertical integrated utility and ID isolated distribution, data reproduced with permission from [23].

\begin{tabular}{ccccccc}
\hline Country & El. Rate & Urban El. Rate & Rural El. Rate & PWE (M) & Grid Price (\$/kWh) & Scheme \\
\hline Benin & $33 \%$ & $58 \%$ & $9 \%$ & 8 & 0.26 & IPP+G\&T+D \\
Burkina Faso & $22 \%$ & $69 \%$ & $2 \%$ & 16 & 0.34 & IPP+VIU \\
Cape Verde & $96 \%$ & $>99 \%$ & $89 \%$ & $<1$ & 0.51 & IPP+VIU \\
Cote d'Ivoire & $76 \%$ & $>99 \%$ & $51 \%$ & 6 & 0.21 & IPP+VIU+ID \\
Gambia & $49 \%$ & $69 \%$ & $16 \%$ & 1 & 0.44 & IPP+VIU \\
Ghana & $85 \%$ & $93 \%$ & $75 \%$ & 5 & 0.14 & IPP+G+T+D \\
Guinea & $46 \%$ & $84 \%$ & $24 \%$ & 7 & 0.35 & IPP+VIU \\
Guinea-Bissau & $28 \%$ & $56 \%$ & $7 \%$ & 1 & 0.66 & IPP+VIU \\
Liberia & $12 \%$ & $18 \%$ & $6 \%$ & 4 & 0.33 & IPP+VIU+ID \\
Mali & $50 \%$ & $78 \%$ & $28 \%$ & 10 & 0.19 & IPP+VIU+ID \\
Niger & $14 \%$ & $71 \%$ & $2 \%$ & 20 & 0.21 & IPP+VIU+ID \\
Nigeria & $62 \%$ & $91 \%$ & $30 \%$ & 77 & 5.35 & IPP+G+T+D \\
Senegal & $71 \%$ & $94 \%$ & $50 \%$ & 6 & 0.55 & IPP+VIU+ID \\
Sierra Leone & $26 \%$ & $52 \%$ & $6 \%$ & 5 & 0.33 & IPP+G\&T+D \\
Togo & $43 \%$ & $77 \%$ & $19 \%$ & 5 & & IPP+G\&T+D \\
\hline
\end{tabular}

Electricity markets in West Africa rely on different schemes regarding the vertical integration from generation to distribution (depicted in Table 1). While some countries rely on independent power producers (IPP) and vertical integrated utilities (VIU), covering generation, transmission, and distribution, others rely on different companies in charge of each process. In this line, different kinds of subsidies apply depending on the vertical integration scheme. The authors refer to the work in [23] for a detailed study regarding the cost calculation of on-grid electricity in West Africa. Specifically, prices charged for on-grid electricity users have a regional average of $\$ 0.35 / \mathrm{kWh}$. In Liberia, Sierra Leone, and Cape Verde electricity pricing was $\$ 0.66 / \mathrm{kWh}, \$ 0.55 / \mathrm{kWh}$, and $\$ 0.51 / \mathrm{kWh}$, respectively [22]. These electricity prices are significantly higher than the LCOE of utility scale on-grid PV for this region, but also in the range of LCOE of hybrid PV-diesel mini grids provided in the last study by the World Bank in June 2019, a concept that could be denoted as "mini grid parity cost", which gives an idea of how competitive these mini grids are in some countries of the region [5].

The West African Power Pool (WAPP), the electricity market for ECOWAS countries, is being established (2016-2025) to interconnect the continental ECOWAS countries (currently only nine countries are interconnected) and improve the quality of the service through 
less unserved demand and integrating more renewables due to the enormous renewable energy resources of this region. It is noteworthy that losses of on-grid electricity due to technical losses (transmission and distribution lines, transformers, and meters) and non-technical losses (theft, non-payment, and errors in measurements) averaged $39.5 \%$ in ECOWAS (indeed, as high as 59\% in Liberia and 57\% in Nigeria) by the ECOWAS Centre for Renewable Energy and Energy Efficiency (ECREEE) [24]. In this line, discrepancies in technical losses were found between values of ECREEE for 2017 [24] and the World Bank estimates for 2014 [25]. The fact that satisfied demand in the region in 2016 was 58 TWh and the projected demand for 2030 is 244 TWh [24] will make strong national plans in reducing losses, improving interconnections and on grid power supply necessary [24,26,27].

\subsection{Installed Mini Grid Capacity in West Africa}

In this study, the latest data available confirmed by the Ministries of ECOWAS countries throughout the ECREEE (April 2020) were collated [28]. Table 2 depicts the 385 mini grids deployed in West Africa: 179 based on PV and 182 based on hybrid PV-diesel, respectively. Both technologies showed the greatest development in the past and according to the latest data of LCOE for the region will likely remain predominant in the upcoming years. Senegal (131 mini grids), Mali (75), Sierra Leone (61), and Nigeria (40) are the countries with deeper integration of mini grids in West Africa. Nevertheless, the strong efforts and plans for rural electrification in this region will significantly modify these numbers. For instance, the 90-mini grid plan in Sierra Leone coordinated by UNOPS and developed by the Ministry of Energy and private independent power producers is currently under construction.

\subsection{Mini Grid Deployment and Tenders}

The trajectory of village-sized mini grids started in the turn of the millennium in some countries of West Africa (Senegal, Burkina Faso, and Mali) and also Morocco, with more than 200 systems by 2018 [29]. While the first mini grids were financed with donors and international support, lately, a strong inclusion of private companies focusing on the business of mini grids for rural electrification has been seen. Some of these companies started to operate targeting the high energy demand segment of rural population with "Tier 2" electricity access ( $>50 \mathrm{~W})$ [11] offering electricity prices of $\$ 0.8 / \mathrm{kWh}-\$ 5 / \mathrm{kWh}$, significantly higher than those offered in the main grid but in some cases around $20-50 \%$ lower than their previous expenditure in fossil fuels. This was channeled throughout the ECREEE and the Banque Ouest Africaine de Développement (BOAD) with the Regional Off-Grid Electrification Project (ROGEP). The ROGEP is being financed by the World Bank, including the ECOWAS countries and also Cameroon, Central Africa Republic, Chad, and Mauritania. The aim pursued with ROGEP is the promotion of renewable energy technologies in the region to achieve $10 \%$ of electricity generation with renewables by 2020 and $19 \%$ by 2030 . Mini grids are promoted via addressing market limitations and suitable public policies to scale-up off-grid initiatives [30]. 
Table 2. State-of-the-art of mini-grid installations in West Africa updated to 2020. Data reproduced with permission from the work in [28].

\begin{tabular}{|c|c|c|c|}
\hline Country & \# Mini Grids & Tech. & Power $(k W)$ \\
\hline Benin & 7 & PV & 205 \\
\hline Burkina Faso & 3 & PV-diesel & 415 \\
\hline Burkina Faso & 10 & PV & 109 \\
\hline Cape Verde & 4 & PV-diesel & 240.8 \\
\hline Cape Verde & 1 & PV-wind & 6.25 \\
\hline Cape Verde & 2 & PV & 42.5 \\
\hline Cape Verde & 1 & PV-diesel-wind & 80.16 \\
\hline Cote d'Ivoire & 7 & PV-diesel & 473 \\
\hline Gambia & 1 & PV-diesel & 64 \\
\hline Ghana & 5 & PV-diesel & 379 \\
\hline Guinea & 3 & Hydro & 3570 \\
\hline Guinea Bissau & 1 & PV-diesel & 602 \\
\hline Guinea-Bissau & 1 & PV & 108 \\
\hline Liberia & 2 & Biodiesel & 85 \\
\hline Liberia & 11 & PV-diesel & 311.2 \\
\hline Liberia & 1 & Hydro & 60 \\
\hline Liberia & 1 & Hydro-diesel & 7800 \\
\hline Mali & 9 & PV-biodiesel & 926 \\
\hline Mali & 1 & Wind-diesel & 376 \\
\hline Mali & 1 & PV-wind-diesel & 264 \\
\hline Mali & 11 & Biodiesel & 672 \\
\hline Mali & 41 & PV-diesel & 14,247 \\
\hline Mali & 12 & PV & 125.5 \\
\hline Niger & 3 & PV & 97.5 \\
\hline Nigeria & 38 & PV & 1210.8 \\
\hline Nigeria & 1 & PV-diesel & 85 \\
\hline Nigeria & 1 & Biomass & 20 \\
\hline Senegal & 98 & PV-diesel & 1488 \\
\hline Senegal & 32 & PV & 536.4 \\
\hline Senegal & 1 & Bioenergy & 30 \\
\hline Sierra Leone & 60 & PV & 1175 \\
\hline Sierra Leone & 1 & PV-hydro & 10.5 \\
\hline Togo & 14 & PV & 725 \\
\hline
\end{tabular}

In 2019, different mini grid initiatives started offering energy-as-service. With this system, developers own and operate the mini grid, assuming the installation and O\&M with customers paying for the service as well as, generally, a connection fee, without assuming the installation risks. The market of mini grid start-ups was testimonial in 2013 and 2014 and raised to $\sim \$ 60$ million/year in 2016-2018. Nevertheless, it is remarkable the fact that, with the latest data available, in 2019 mini grid market doubled to $\$ 113$ million, while the market for SHS and solar lanterns shrank significantly to \$198 million. This change in technology trend is supported by the enormous interest that energy-access startups for mini grids have in SSA [31]. These figures show a trend in which mini grids are attracting higher interest to investors. This is also followed by the appearance of national tenders that seek to introduce mini grids in their previously selected locations. Traditionally, national tenders in Africa (16 countries up to 2019) offered concessions for investors with the exclusivity for development and operation of mini grids in their area, in which the role of seeking for locations and capacity building corresponded to the government. This approach reduced the uncertainty of investing in mini grids in locations with a future grid extension. However, this type of tenders proved inefficient as the strong competition left many projects without installing. Instead, it proved more efficient the result-based financing (RBF) tenders in which it was subsided the installation once built. This RBF tenders came out in 2019 in six African countries Algeria, Ethiopia, Mali, Burkina Faso, 
Togo, and Nigeria [31]. These bidding processes all coincide in receiving assistance from international development and donor institutions.

The Mali tender was coordinated by L'Agence Maliene por le Développement de $l^{\prime}$ Energie Domestique et l'Electrification Rurale (Amader) and financed by the Islamic Development Bank (13.5 million euro) for two PV installations with combined capacity of 1.3 MW (each) and 1.5-2 MWh battery storage to provide electricity to 24 villages. According to Amader, this is part of a $4.83 \mathrm{MW}$ PV plan to electrify 70 villages [32].

The Burkina Faso tender (the Yeleen project) is funded with 74.8 million euro from different institutions: African Development Bank, Green Climate Fund, European Union, Burkina Faso Government, ABER, and private developers for 100 projects to be developed between 2019 and 2022 offering a 16.2\% profitability [33]. A result-based grant will be provided for each proved electricity connection as well as loans for productive use and support in the construction of the renewable energy infrastructure [34].

The Togolese Rural Electrification and Renewable Energies Agency (AT2ER) launched in 2019 a tender of 317 mini grids to be financed by the West African Development Bank (BOAD) and the Energy Development Fund (FDE). This project consists of five lots divided in three phases integrating $11 \mathrm{MW}$ and $480 \mathrm{~km}$ of distribution lines [35].

The Nigerian RBF tender, coordinated by the World Bank and the Rural Electrification Agency, started from an initial 2000-project study in which finally 250 sites were selected according to the density and number of potential customers and the proximity to infrastructures and businesses. In order to achieve economies of scale, IPPs were required to bid for more than one project. The RBF was based on a $\$ 350$ subsidy per customer connected [36,37]. Besides, the Rural Electrification Agency seeks to promote PV mini grids in 44 Nigerian universities and teaching hospitals that rely on diesel generators.

\section{State-of-the-Art of Mini Grid Research in West Africa}

The trajectory of village-sized mini-grid deployment in West Africa started at the beginning of the century under different donors and scattered international funding programs. Since then, despite the significant growth of mini grids in West Africa, the bibliography related has come from a narrow variety of scientific approaches and accurate information regarding the present status is still scarce and frequently related to SSA, a much larger area, covering 49 different countries. In this line, a systematic review was performed and the analysis of the results was organized into subfields.

The systematic review was performed to include reports and academic studies based on two different filters focusing on studies published from 2000 to 2020 (December). The initial filter was based on search queries in Scopus and Google browser using as keywords: "mini grid" OR "micro grid" OR "rural electrification" OR "off-grid" OR "energy" AND "West Africa" OR "ECOWAS" OR each country name belonging to West Africa (i.e., "Ghana"). The adequacy and contribution of articles falling within the initial filter was personally analyzed by the authors. The second filter was performed to avoid the omission of articles not falling within the search keyword queries of initial filter. The bibliography cited in those studies included in the first filter were a matter of particular analysis to determine the adequacy to be included in the review. This second filter was applied until convergence was reached; therefore, no studies contributing to the field appeared in the bibliography of filtered articles. Then, to facilitate the reading we have classified in five categories, the subjects analyzed in the review of the papers: evaluation of mini grid potential, welfare impact of mini grids, policies and barriers for rural electrification, demand side analysis, and mini grid reliability.

\subsection{Evaluation of Mini Grid Potential}

Different authors elaborated methodologies and specific tools to calculate the potential of renewable energies for rural electrification in SSA. These applications can be of interest in the design of public policies for national electrification as they provide insights regarding the levelized cost of electricity (LCOE) of different technologies, cost comparison between 
on-grid and off-grid approaches, location of off-grid installations, and potential users of mini grids. Specifically, the ECOWREX open online tool offers up-to-date monitoring of ongrid and off-grid installations in West Africa with data contrasted by national governments and private developers [38-40]. In parallel, the RE2NAF open tool developed by the Joint Research Centre-European Commission allows to compare the levelized cost of electricity of PV and diesel generators for the African continent [41-43]. Further research was published by Cader et al. (2016) [44], who compared the LCOE differences between off-grid diesel systems and hybrid (PV-diesel-batteries) installations with geographical information systems (GIS) covering West Africa. The authors concluded that in the majority of this region it was possible to reduce the LCOE by $0.06-2$ euro/ $\mathrm{kWh}$ considering PV hybrid systems. In the line of GIS studies, Moner-Girona et al. (2018) [45] reviewed different GIS tools for rural electrification to analyze in which manner they are providing help to the fulfillment of the SDGs. As another free tool, the National Renewable Energy Laboratory (NREL) released a mini grid calculator to estimate the load capacity and LCOE [46].

Besides, the Global Electrification Platform offers a tool to calculate future projections and scenarios for on-grid and off-grid LCOE PV costs for SSA [47]. Another open application is the Off-Grid Market Opportunity Tool, which provides public GIS information regarding potential users of mini grid systems [48]. Particularly for West Africa, the IMPROVES-RE service offered off-grid installation data for Burkina Faso [49]. Furthermore, specifically for Burkina Faso $[50,51]$ covered the evaluation of the least-cost electricity option considering mini grids, interconnection to the main grid and standalone systems.

On the other side, different country-specific mini grid analyses were performed in order to compare off-grid and grid extension approaches to achieve higher electrification coverage in Senegal [52] and to evaluate the total renewable energy potential in Cote d'Ivoire [53]. A different perspective was considered by Sawadogo et al. (2020) [54] in which the impact of solar irradiation variability along the year in the design of PV systems in Western Africa was analyzed. Variations of $8-25 \%$ in the annual cycle were observed in the PV generation. A GIS map was provided with the preference of both approaches considering the following as fundamental factors: population density, distance to grids and roads, proximity to protected areas, and the solar resource. In most of the West African region, conclusions showed that PV off-grid was moderately suitable in the terms of the study.

\subsection{Welfare Impact of Mini Grids}

Electricity use allows a wide variety of economic activities that help rise gross domestic product of population connected. Consequently, different authors studied the impact of off-grid rural electrification into energy poverty and welfare. Ghana, in particular, as the case scenario, has been analyzed from different perspectives. Obeng et al. (2008) [55] performed 209 questionnaires in off-grid PV-electrified and non-electrified households concluding that savings on lighting, number of children who can sit around lighting, and expenditure in energy are the factors influencing most on the energy poverty index score. On the other side, energy poverty was related to urban and rural population in Ghana, where the rural population is almost twice as energy poor as urban population. National strategies to reduce spatial poverty should be accompanied with modern and affordable energy sources [56]. Despite national strategies, different socio-economic factors (household expenditure, employment, and gender of family head) affect the success in rural electrification and the consequent welfare impact [57]. Lin and Ankrah (2019) [58] stated that impact of renewable energy into Ghana's national economy is still low due to the prevalence of conventional technologies. Adenle (2020) [2] evaluated the impact of rural electrification with PV for the fulfillment of the SDGs finding clear socio-economic, environmental, and health benefits.

The welfare impact of mini grids on health and education has been scarcely referred in literature. In the case of education centers and health posts located in areas without interconnection, whose activities rarely generate revenue, the access to electricity through 
mini grid introduces the necessity of solving the economic sustainability of CAPEX and OPEX [59].

The measurement of welfare impact due to rural electrification is complex as the cost of electricity access clearly segments population. Only by looking at the evolution in household welfare between previous and after electrification is possible to account the difference. In Gambia, it was concluded that the declining cost of off-grid PV should be considered as crucial for social and economic development [60].

Furthermore, a review about the impact of renewables into economic growth was performed for West African countries considering the period 1995-2014, when renewables were mainly attributed to wood biomass for cooking [61]. Results showed a direct relation between renewable energy use and decrease of economic growth. In the same study, PV electrification and a greater commitment of national authorities were recommended to reduce the negative impact of biomass into health and environment. Nevertheless, the substitution of biomass wood, whose main application was cooking and water heating, is not optimally achieved with mini grids due to the high cost of electricity and both energy sources are frequently combined.

Some international initiatives such as the SEforALL institution via the Green MiniGrid Market Development Program (GMG MDP), funded by the Sustainable Energy Fund for Africa (SEFA), seek energy poverty reduction via introducing renewable energy mini grids, with an estimated of 150,000 mini grids required in Africa by 2030 [62]. Besides, the USAID-NREL [63] provides technical information for mini grid sizing according to the business and economic sector and the social and economic impact of the productive use of energy.

\subsection{Policies and Barriers for Rural Electrification}

Success and failure of rural electrification with mini grids generally relies on public policies and regulatory framework. Different authors evaluated how ambiguous institutional policies, implementation weaknesses and coordination issues were responsible of the poor deployment of rural electrification in West Africa. Atuguba and Tuokuu (2020) [64] analyzed the slow PV deployment in Ghana, recommending the consolidation and application of renewable energy laws and policies to move the renewable energy agenda forward. Obeng-Darko (2019) [65] also explained the failure in the integration of renewable energy sources in Ghana-the 100\% electrification and 10\% renewable energy targets by 2020, due to the lack of legislation necessary to fulfill the targets and the investors uncertainty. Besides, cost effectiveness and market driven schemes should be prioritized to eliminate barriers to renewable energy electrification in Ghana [66].

The Green Investment Diagnostics methodology was proposed to analyze constraints that penalize the electrification growth. The regulatory uncertainty, coming from macroeconomic imbalances and policy-makers, was found to be a crucial factor as well as the costly domestic finance using this methodology [67].

Another barrier for mini grid installation was related to the lack of updated LCOE information. Moner-Girona et al. (2018) [68] developed a multidimensional analysis to evaluate costs of hybrid PV-diesel mini-grids, finding a significant gap in costs between business models and built projects, also between SSA countries, which acts as a barrier for investors and policy makers with this technology. Furthermore, the LCOE of off-grid PV in Africa was strikingly high due to custom taxes and lack of competency, which act as barriers for private investors and final users [69].

Ockwell et al. (2018) [70] focused on the political and socio-cultural factors and barriers to achieving the 2030 renewable energy targets in SSA. The authors concluded that the social barriers have not been deeply addressed in the literature, and they are expected to play a crucial role as in other fields in developing projects. According to the same authors, policy-makers should take into account these non-technical factors in their agenda.

The mini grid policy was evaluated in Ghana concluding that the lack of licensing regulation explained that most of the mini grids installed are donor-funded and govern- 
ment owned [71]. Furthermore, uncertainties in mini grid tariffs for private mini grid development explained the lack of private mini grid success in Senegal [72]. The same barriers seen in Ghana and Senegal also apply to Cote d'Ivoire [73]. However, Niger is changing regulation to support private mini grid development through clearer regulation and business models. Still, uncertainties of how mini grid operators would be compensated if grid extension occurs, how restriction would apply to mini grid component imports and which mechanisms would be applied for tax regulation and mini grid quality assurance should be solved [74].

The success factors of the Nigerian mini grid development were covered through specific past regulations and analyzed for augmenting the mini grid market. In this line, Nigeria has a specific tool for mini grid tariff setting, the MYTO tool, seeking to obtain higher transparency in tariffs with different regulation for off-grid mini grids and interconnected mini grids [75-77]. The success in mini grid deployment in Mali was attributed to the regulation with subsidies for each new connection [78].

Seeking to simplify the access to mini grid private developers and operators, the Mini Grid Help Desk tool, developed by the African Development Bank, puts together information of regulation, permits, and taxes required for mini grid development in ECOWAS [79].

\subsection{Demand Side Analysis}

The low economic activity of rural areas in Western Africa leaves mini grid users with a potentially lower willingness to pay for electricity than in other more developed locations. On the other side, the demand for electricity in these areas generally comes from small family businesses and homes whose energy expenditure is low. These factors can make the mini grid amortization less competitive against other off-grid systems such as SHS and diesel generators. Some authors evaluated the demand side requirements and the willingness to pay in Liberia, where a suppressed demand in rural areas of $235 \mathrm{GWh} / \mathrm{yr}$ was estimated, which could be satisfied with renewables [80]. The conclusions of that study pointed out that the lower capital cost of diesel generators makes the initial investment more attractive than PV, even though the LCOE is lower for PV. The authors also concluded that the combination of centralized and decentralized electricity, the latter with policy support and funding, is necessary to achieve universal access in the country. A similar study was performed in Senegal considering also the environmental externality costs in the evaluation concluding that PV based off-grid systems were more attractive in economic terms than grid extensions in the locations analyzed [81].

The economic impact of mini grid systems was particularly analyzed in eight microenterprises in Ghana concluding that electrification contributes to savings of $\$ 1-5 /$ month in illumination compared to kerosene and also contributed to an income surplus of $\$ 5-12 /$ day due to opening after sunset, which gave a competitive advantage against other businesses [82].

In Benin, different technologies were compared for rural electrification. From the demand side, it was concluded that hybrid PV-diesel considering a $150 \mathrm{~kW}$ PV generator with a $62.5 \mathrm{kVA}$ diesel generator and a $637 \mathrm{kWh}$ battery storage achieved the lowest LCOE and led to a reduction in battery requirements of $70 \%$ compared to PV-battery systems. Hybrid PV-diesel mini grids were recommended in this country instead of the widely installed PV-battery systems [83].

The particular analysis of mini grid energy demand and site selection using surveys was evaluated by Williams et al. (2019) [84].

\subsection{Mini Grid Reliability}

Another research field is related to the mini grid reliability. This has been approached from a variety of perspectives such as solar resource, reliability of batteries, degradation of PV modules, and reliability of mini grids versus national grid [85]. Regarding the solar 
resource, it was approached to account for the low solar irradiation profiles to design 100\% solar systems [86].

Regarding technical issues, batteries represent the weakest component in PV minigrids due to the relation between life cycle and adequate system use. Lead-acid batteries are commonly distributed in Western Africa countries and represent the majority of the storage technology in mini grids. However, their lifespan is short, and many systems fail due to financial constraints when substitution. A technical analysis of Li-ion batteries in ECOWAS countries was performed by Diouf and Avis (2019) [87], concluding that Li-ion batteries should replace lead-acid batteries in this region.

Reliability of off-grid systems was also studied in this region through the aging and degradation of 22 PV monocrystalline modules exposed for 16 years in Ghana, concluding that decline was in the range of 18 to $39 \%$ during this period (median degradation rate of $1.54 \%$ /year). Discoloration of encapsulant and degradation of junction-box adhesive were also frequently recorded [88].

In parallel, other studies showed the real performance of PV grid-tied in Ghana [89] and Sierra Leone [90], which are of interest to evaluate how on-site specific conditions in the region affect PV performance.

A different perspective was approached throughout the improvement in on-grid connectivity and national interconnections as alternative to off-grid electrification [21,91,92]. Besides, PV off-grid was analyzed as back-up technology for electricity customers in Ghana who require higher electrical availability than that offered by the national grid [18].

\section{Challenges for Mini Grid Deployment in West Africa}

This section shows and discusses some of the challenges for mini grid deployment in West Africa. The methodology to elaborate this section is as follows. Based on the selected papers of the systematic review in previous Section 3 and on the texts consulted for Section 2, we have detected the challenges when developing mini grids in West Africa. Usually, the authors of those texts remarked at the discussion section some of the challenges they had observed during either their research or the analysis of those mini grids. Some of the identified papers using the aforementioned keywords filters were not used for Section 3, but were interesting to understand the challenges of mini grid deployment and were consequently incorporated into this section.

Furthermore, three key opinion leaders (off-grid and mini grid consultants and developers at United Nations Office for Project Services (UNOPS), Mott MacDonald, and Fundación EKI) were telephonically interviewed to collect their ideas about current issues when developing these mini grids and future challenges that need to be taken into account to facilitate the extension of this technology in the region.

In order to ease the presentation of these challenges, authors have classified all the elements obtained from the literature as well as from the experts, in several sections: financial challenges, cost challenges, social and environmental challenges, communitybased challenges, and regulation challenges.

\subsection{Mini Grid Financial Challenges}

Mini grid financing in West Africa represents the main challenge for its deployment. Capital costs remain high due to factors such as high custom taxes and lack of economies of scale, which are still far to be achieved. On the other side, the investment risk is usually high due to the combination of country-risk (higher in West Africa than in other regions), combined with other denoted factors: financing mechanisms, stability of regulatory framework, and bureaucracy.

- $\quad$ Financing mechanisms: most mini grid projects in this region rely on international donors or cooperation agencies for funding, who work in cooperation with national governments to develop tenders in which independent power producers (IPPs) bid in the electricity price offered along a certain period assuming the engineering, procurement, and construction (EPC) cost and O\&M costs. This methodology has been 
designed to create a business model attractive enough to gain private interest. Some of the most recently announced internal rates of return were in the range from 10 to $15 \%$ and electricity prices offered to customers around $\$ 0.85 / \mathrm{kWh}$ (i.e., the 90 mini grid 2019-2020 project in Sierra Leone, under development). In this line, the World Bank announced in 2019 a $\$ 150$ million line of funding and a $\$ 75$ million recovery grant to foster off-grid electricity in 19 countries of the ECOWAS and Sahel region [93].

- Stable and continuous regulatory framework: despite the long tradition of public regulation for utility-scale PV deployment, tenders for mini grids are relatively recent and imply previous strategic decisions regarding the choice of grid extension or mini grid, as well as identifying optimum sites, required capacity and discussing with the local community. This has been proved complex and time-consuming, and explains why only 16 African countries had tenders for mini grid concessions by 2018. Some of these tenders proved inefficient when electricity price competition left low benefits for IPPs, i.e., Senegal only deployed three out of 10 tendered mini grids (2008-2013). The recently implemented RBF or feed-in tariff started in 2019 to improve the efficiency of tenders. This way, the IPP receives a fixed subsidy per connected customer or kWh generated. With this, four West African countries launched tenders in 2019: Mali (two mini grids), Burkina Faso (100 mini grids), Togo (317 mini grids), and Nigeria (250 mini grids) [31].

Another factor related to the regulatory framework is the "arrival of the main grid factor". Most of the West African countries analyzed do not have clear regulations in the event of grid extension in sites with previous mini grids and how expropiation of mini grid and distribution line built for the mini grid would be compensated [94]. This introduces a higher financial risk for mini grid development in off-grid sites nearby to the main grid than for remote locations.

- Bureaucracy: public regulation for mini grids in West Africa is tender-based, which generally implies different terms, conditions, and requirements for each tender. This introduces unknown bureaucratic processes and timings in each tender with the subsequent financial risks for developers. Note the case study of Senegal in which bureaucracy took five years to award the first mini grid concession from the tender and another five years to get the first household connected [94].

\subsection{Mini Grid Cost Challenges}

Nowadays, with a wide range of mini grid configurations and technologies considered, the CAPEX and OPEX of mini grids have an enormous variability. The lack of transparency in mini grid tenders and the subsequent updated mini grid cost information also contribute to a higher dispersion of values [68].

- $\quad$ Reduction of CAPEX: with the aim of comparing installation costs, the firm power output (firm) was created to denote the power that can be supplied by the mini grid at any moment (i.e., for a hybrid PV-diesel mini grid it is the added capacity $\left(W_{\text {firm }}\right)$ of diesel generator and battery inverter). According to the global survey by the World Bank, with 53 mini grids considered, capital costs ranged from $\$ 1.42$ to $22.7 / W_{\text {firm }}$ in 2018 . In the same study, a median cost of $\$ 4.3 / W_{\text {firm }}$ was obtained removing mini grid outliers higher than $\$ 8 / W_{\text {firm }}$, which indeed was the median cost in 2010 [5]. This reduction in capital costs by half in PV mini grids can be explained by the boom experienced by PV in the last decade and the economies of scale applying to PV panels, inverters, structures, smart meters, and batteries, which have decreased by $60-85 \%$ for utility scale power plants in the same period. Nevertheless, the reduction in cost for these components in mini grids has not been as pronounced as for utility scale, i.e., PV modules for mini grid were in the range of $\$ 0.69 /$ Watt-peak versus for utility scale \$0.25-0.3/Watt-peak. These cost inefficiencies present a CAPEX challenge that might be improved when economies of scale apply to mini grid developers. In this line, the continuous decrease in cost of mini grid components, especially for batteries (Li-ion) due to the development of the electric car will contribute to further CAPEX reductions. 
It is noteworthy that project-associated costs can also be reduced using geo-planning tools for design. Table 3 depicts the share in CAPEX of the main components, which accounted for $56-60 \%$ of the overall cost [5].

Table 3. Share of mini grid CAPEX by component based on the World Bank survey. Reproduced with permission from [95].

\begin{tabular}{cc}
\hline Component & Share in CAPEX \\
\hline PV modules & $11 \%$ \\
PV racks & $3 \%$ \\
PV controller & $5 \%$ \\
Genset & $3 \%$ \\
Inverter & $9 \%$ \\
Battery & $15 \%$ \\
Monitoring & $1 \%$ \\
Power house & $7 \%$ \\
Distribution grid & $14 \%$ \\
Public lighting & $1 \%$ \\
Meters and service connections & $4 \%$ \\
Customer systems & $3 \%$ \\
Logistics & $6 \%$ \\
Installation & $9 \%$ \\
Project development & $9 \%$ \\
\hline
\end{tabular}

- Reduction of OPEX: OPEX accounts to $35-40 \%$ of the LCOE share [31]. Maintenance and failure detection performed by local staff with the support of remote monitoring technicians, who manage simultaneously several mini grids, lead to savings in OPEX by increasing component lifetime and replacement costs, and reducing downtimes caused by diagnosis visits [96]. In this line, staff costs (salaries and related expenses associated to basic maintenance) account for $76 \%$ of all operation costs [95]. Besides, novel systems for payment collection combining smart meters and credits purchased with cellphones, a very popular method for other payments among West African countries, also contribute to reducing OPEX.

- Improvement of load factor: reducing CAPEX and OPEX is a way to reduce the LCOE but it can also be achieved improving the load factor. LCOE can be reduced from the range of $\$ 0.65 / \mathrm{kWh}$ to $\$ 0.42 / \mathrm{kWh}$ with load factors of 0.22 ( 0.22 is a frequently load factor in mini grids) and 0.4, respectively [5]. In this line, a consumption profile more related to the availability of the solar resource contributes to downsizing batteries and lowering fuel use. Further research and experience are required to evaluate how mini grids improve the local economy and how this impacts the load factor along the mini grid lifetime.

\subsection{Mini Grid Social and Environmental Challenges}

Not only do technical factors impact mini grid investment risks, but also social factors do, whose literature is scarce and their importance is crucial for mini grid success. Some of the social factors that we have registered have been obtained from interviews with mini grid consultants and installers in West Africa. Most social factors are local and might differ from one project to another.

- Social acceptance of mini grid: engagement with early meetings, training in operation and maintenance, impact to the community, and transparence on the role of the mini grid operator with the community, especially with other existent businesses, are fundamental to reduce the risk of project failure [63,85,97-99]. In this line, the Minigrid Game initiative seeks to increase acceptance and at the same time educate the local population on how a mini grid operates and how they can become responsible consumers understanding how their actions affect all mini grid users [100]. 
Furthermore, in some regions and communities it is necessary to obtain project approval by regional and local chiefs. This is a very local factor and requires specific knowledge of how the local community works, identifying key social stakeholders. This might be sensitive to corruption and delays in project execution if social acceptance is desired [101]. Another registered factor is the necessity of getting a quality site for the PV-battery-power house installation, poles, and wiring. For this it might be necessary to cut relevant trees for the community in terms of food, shade, or tradition or moving businesses; depending on the ownership of the land, communitary, etc., this can be a complex factor [102]. If not socially accepted, it is relatively common that some mini grids PV panels are destroyed by the throwing of stones or stealing of main components. On the other side, SHS generally do not require this community acceptance, chief approval, or interventions into other's land.

- Social impact of electricity access to the community: the consequent improvement in job creation and businesses might generate higher electricity consumption and therefore improve the load factor, lowering the LCOE and potentially the price charged for electricity [103]. The study of the electricity demand evolution depends on social and economic factors such as development of the community with the access to electricity, industrialization, evolution of the alternative technology SHS cost, evolution of the electricity tariff and quality of service of mini grid along the life cycle, etc.

- Technology preference between the mini grid and SHS. This factor depends on the ownership tradition or the SHS positive acceptance in the community. In some cases, it might fall in a SHS property preference instead of paying for service and relying on the conditions of mini grid operators. If mini grid electricity price or access to electricity is sufficiently high, it will attract customers to SHS. Furthermore, DC appliances for SHS are currently more expensive than the equivalent for AC, but this might change over the time. If so, DC SHS might get more attractive [104].

- Electricity metering: some smart meters sum the consumption of more than one client, but then it is charged and divided for all equally, which generates social complaints. The higher the transparency with metering the better to gain social acceptance [102].

- Urban exodus: this factor has been scarcely described. Despite the positive impact of mini grids to small enterprises, mini grids lead to improvements in higher education, which might accelerate rural exodus and urban expansion [102].

- Gender impact: different studies revealed that women were 9-23\% more likely to gain employment with access to electricity [63]. This was explained by the fact that domestic activities were performed in the evening using mini grid electricity and remunerated work during the day time. Nevertheless, many entrepreneurship programs derived from electrification are focused on male-associated industries [104].

- Health and environmental impact: the reduction of kerosene for lightning and diesel or biomass for energy has a positive impact for population. However, cooking with inexpensive charcoal or wood instead of electrical resistances (considering a reference value for electricity of $1 \mathrm{kWh}$ or $\$ 0.85$ for one hour of cooking) poses a challenge for mitigating deforestation and reducing lung-associated diseases, especially for women in extremely poor regions. As a result, electricity is left for illumination and charging appliances [102].

Regarding the environmental impact of power generation, it is generally approached through the Life Cycle Assessment (LCA) methodology considering different environmental scores $[105,106]$. LCA for mini grids in West Africa remains a field to be studied. Besides the LCA, the end-of-life of components constitute a critical issue, a topic that has been scarcely referred in literature. The treatment of batteries, PV modules, and electronic components at the end-of-life constitutes a challenge to be considered in scenarios with a high mini grid share [107]. 


\subsection{Mini Grid Community Engagement Challenges}

Lessons learned from other fields for community development in West Africa such as health, water, and sanitation have shown the importance of communication, community engagement, and sustainable O\&M as crucial factors for success in these projects [108]. A critical issue for community engagement is the spatial energy justice (related to the cost and quality of energy within a country), which should motivate the equiparation between grid connected and off-grid populations within the same country [56,109-111]. Rural electrification policies based on SHS or mini grids designed below real necessities have been considered as the "solar trap" [112], or "illuminated but not electrified" [113]. Under this, rural populations have access to a weak power source only adequate for illumination but not for developing commercial activities or using conventional electrical appliances typical of grid-connected areas. This low electricity access can turn into a future inconvenience for these communities as they can be externally considered as electrified, and therefore being out of future considerations for mini grids or grid extensions.

The LCOE of mini grids relies on the expected future consumption, which is related to cultural and economic driven factors [84]. The fact that these systems usually serve for users who lack of basic electric coverage, the initial access to electricity might multiply consumption more than expected during the design of systems, with effects known as the Jevon's paradox or rebound effect: the cheaper the use of energy the higher increase the overall consumption of energy [114,115]. On the opposite side, it has been frequently recorded load factors and consumption profiles below designed [116], which implies LCOE higher than initially expected. Unlike utility-scale renewable energy projects with PPA signed, with regulatory frameworks and financial models depending on the tariff and energy generated, off-grid mini grids integrate other sources of uncertainty such as the estimation of electricity consumption along life cycle, hybridization share based on consumption profiles, life cycle of batteries according to discharge profiles, etc. Thus, further knowledge regarding mini grid community engagement and mini grid use would lower the financial risk associated to the evolution of mini grid load factors.

\subsection{Mini Grid Regulation Challenges}

Financial risk accompanied with strong competition in tenders might be one of the reasons explaining the low efficacy of achieving objectives in tenders prior to 2019 in West Africa. The fact that regulatory framework for mini grids is tender-based in West Africa and generally different in each tender, instead of a continuous regulation with a clear roadmap, introduces higher risk for developers. Derived from this lack of stable regulatory framework, it is notorious the lack of any regulation for grid extension events in sites with existing mini grids and how expropriation of mini grid and distribution lines associated would be compensated [94]. This introduces a higher financial risk in sites nearby from national grid than for remote locations. Furthermore, the tender-based regulation with different requirements and public approvals in each tender can be a potential source for further delays associated to bureaucracy [94].

\section{Future Research}

The state-of-the-art of mini grids in West Africa leaves some areas that should deserve further research attention. In this line, there is a general lack of social analysis of mini grids that should answer questions such as social variables affecting the choice of mini grid versus SHS, strategies to improve social mini grid acceptance, daily profile use associated to the solar resource to reduce battery sizing and fuel use, evolution of mini grid load factor associated to community engagement and intrinsic economic development associated to the installation of the mini grid, smart metering technologies to improve transparency, impact of mini grid to gender and health, and cooking with electrical devices plugged into the mini grid versus traditional cooking with biomass. Regarding the environmental research, the life cycle assessment considering grid extension, SHS and mini grids deserves special attention in West Africa as well as the end-of-life treatment of mini grid components. 


\section{Summary and Recommendations}

The fulfillment of the SDG7 in West Africa is extremely challenging due to a current electrification rate below $50 \%$, which is especially low for rural populations. Only Cape Verde, Cote d'Ivoire, Ghana, and Senegal had rural electrification rates above 31\%. Besides, quality of service for on-grid users in this region is remarkably low with losses accounting to $39.5 \%$ of the generation, frequent disruptions and noteworthy high electricity prices (i.e., Liberia and Sierra Leone: $\$ 0.66 / \mathrm{kWh}$ and $\$ 0.55 / \mathrm{kWh}$, respectively). These factors combined with the incapacity of national governments for grid extension have made mini grids appealing for rural electrification.

Three-hundred-and-eighty-five mini grids are currently operating in West Africa, of which 170 rely on PV-battery and 188 on hybrid PV-diesel-battery technologies. This shows a prevalence of the PV technology compared to other renewables such as wind or hydro. Recent national tenders in Nigeria (250 mini grids), Sierra Leone (90), Togo (317), and Burkina Faso (100) prove the rising interest for PV mini grids in this region. The latest numbers according to the World Bank show a median PV mini grid firm power output cost of $\$ 4.3 / W_{\text {firm }}$ and LCOE of $\$ 0.55 / \mathrm{kWh}$, in which CAPEX accounts for $60-65 \%$ and OPEX for $35-40 \%$ of the mini grid LCOE. It must be noted that cross-comparison of LCOE among mini grid projects and countries in the West African region is extremely challenging due to different factors such as country risk, financial conditions, mini grid technology and size, specific tender conditions, etc.

Regarding the state-of-the-art in academic research of mini grids in West Africa, a literature analysis was performed analyzing the evaluation of mini grid potential, the welfare impact of mini grids, policies and barriers for rural electrification, the demand side analysis of mini grids, and mini grid reliability. It is remarkable that most of the addressed studies are focused on technology and economic barriers, while little literature is available for the social impact and social challenges of rural electrification with mini grids. The fact that not only technical but also social factors are crucial for the success of mini grids in rural West Africa should demand higher research interest in these social fields.

On the other side, barriers for mini grid deployment in West Africa were analyzed and described according to financial, cost, and social challenges. Most financial barriers reported were related to the regulatory framework and access to funding. Traditional competitive mini grid tenders proved inefficient in achieving goals while the recently implemented RBF tenders in Nigeria and Burkina Faso showed less financial risk for investors introducing subsidies applied per new connection.

It is possible that the greatest financial challenge for mini grids in West Africa still depends on the transition from international aid funding to public and private funding. Regarding costs challenges, both CAPEX and OPEX require economies of scale to reduce the existing inefficiencies as well as seeking to increase the relatively low load factors recorded. However, with the existing on-grid electricity price and the noteworthy mini grid LCOE reduction seen during the last decade it is expectable a parity cost between on-grid and off-grid electricity in some of the ECOWAS countries; particularly in Gambia, Sierra Leone, Liberia, and Cape Verde.

\section{Recommendations}

Based on the state-of-the-art of mini grids in West Africa, the authors have summarized some recommendations that could ease the way to mini grids in this region.

- More transparency in tenders, technologies selected, and prices offered in West African countries would help to design tenders based on the results of neighbour countries, contributing to the access of more developers into this market.

- Mini grid tariffs should be designed and adapted to improve mini grid load factors focusing on activities that add value to the community with rebound effect.

- $\quad$ Regulation should specify compensation conditions for mini grids affected by grid extension to lower the financial risk of off-grid sites nearby to the main grid. 
- Open data of mini grid demand curves would help in the design and optimization of future mini grids reducing the number of assumptions in the design.

- Auditories of mini grid customer satisfaction should be implemented as a way to evaluate social perception and include potential improvements in the design of new tenders.

- Tenders should try to reduce the bureaucratic load as a way to improve their efficacy.

Author Contributions: Conceptualization, F.A.-T.; methodology, F.A.-T. and J.A.; software, F.A.-T.; validation, F.A.-T.; formal analysis, F.A.-T. and J.B.-F.; investigation, F.A.-T.; resources, F.A.-T.; data curation, F.A.-T.; writing—original draft preparation, F.A.-T.; writing—review and editing, F.A.-T., J.A. and J.B.-F.; visualization, F.A.-T.; supervision, J.B.-F.; project administration, F.A.-T.; funding acquisition, F.A.-T. All authors have read and agreed to the published version of the manuscript.

Funding: F. Antonanzas-Torres would like to express his gratitude for the postdoctoral fellowship Juan de la Cierva Incoporación 2018 (IJC2018-037635-I) granted by the Spanish Ministry of Science, Innovation and Universities.

Conflicts of Interest: The authors declare no conflict of interest.

\section{Abbreviations}

The following abbreviations are used in this manuscript:

$\begin{array}{ll}\text { AC } & \text { Alternating current } \\ \text { AT2ER } & \text { Togolese Rural Electrification and Renewable Energy Agency } \\ \text { CAPEX } & \text { Capital expenditure } \\ \text { D } & \text { Distribution } \\ \text { DC } & \text { Direct current } \\ \text { ECOWAS } & \text { Economic Community of West African States } \\ \text { ECREEE } & \text { ECOWAS Centre for Renewable Energy and Energy Efficiency } \\ \text { EPC } & \text { Engineering procurement and construction } \\ \text { G } & \text { Generation } \\ \text { GIS } & \text { Geographical information system } \\ \text { GMG MDP } & \text { Green Mini Grid Market Development Program } \\ \text { ID } & \text { Integrated distribution } \\ \text { IPP } & \text { Independent power producer } \\ \text { LCA } & \text { Life cycle assessment } \\ \text { LCOE } & \text { Levelized cost of electricity } \\ \text { NGO } & \text { Non-governmental organization } \\ \text { NREL } & \text { National Renewable Energy Laboratory } \\ \text { O\&M } & \text { Operation and maintenance } \\ \text { OPEX } & \text { Operational expenditure } \\ \text { PPA } & \text { Power purchase agreement } \\ \text { ROGEP } & \text { Regional Off-Grid Electrification Project } \\ \text { RBF } & \text { Result-based financing } \\ \text { SDG7 } & \text { Sustainable development goal 7 } \\ \text { SEFA } & \text { Sustainable Energy Fund for Africa } \\ \text { SHS } & \text { Solar home system } \\ \text { SSA } & \text { Sub-Saharan Africa } \\ \text { T } & \text { Transmission } \\ \text { UNOPS } & \text { United Nations Office for Project Services } \\ \text { VIU } & \text { Vertical integrated utility } \\ \text { WAPP } & \text { West African Power Pool } \\ & \end{array}$

\section{References}

1. IEA; IRENA; UNSD; WB; WHO. Tracking SDG 7: The Energy Progress Report 2020, Washington DC, USA. Available online: https://www.irena.org/publications/2020/May/Tracking-SDG7-The-Energy-Progress-Report-2020 (accessed on 15 December 2020).

2. Adenle, A.A. Assessment of solar energy technologies in Africa- opportunities and challenges in meeting the 2030 agenda and sustainable development goals. Energ Policy 2020, 137, 111180. [CrossRef] 
3. UN. United Nations General Assembly: Transforming Our World: The 2030 Agenda for Sustainable Development. 2015. Available online: https://sdgs.un.org/2030agenda (accessed on 15 December 2020).

4. ESMAP. Energy Sector Management Assistance Program (ESMAP) Policy Matters: Regulatory Indicators for Sustainable Energy; World Bank: Washington, DC, USA, 2018.

5. ESMAP. Mini Grids for Half a Billion People: Market Outlook and Handbook for Decision Makers. 2020. Available online: https: / / esmap.org/mini_grids_for_half_a_billion_people (accessed on 15 December 2020).

6. Boamah, F. Desirable or debatable? Putting Africa's decentralized solar energy futures in context. Energy Res. Soc. Sci. 2020, 62, 101390. [CrossRef]

7. Bardouille, P.; Muench, D. How a New Breed of Distributed Energy Services Companies Can Reach 500 mm Energy-Poor Customers within a Decade: A Commercial Solution to the Energy Access Challenge; World Bank Collaboration: Washington DC, USA, 2014.

8. IRENA. International Renewable Energy Agency (IRENA), Solar PV in Africa: Costs and Markets; IRENA: Abu Dhabi, United Arab Emirates, 2016.

9. Glemarec, Y. Financing off-grid sustainable energy access for the poor. Energ Policy 2012, 47, 87-93. [CrossRef]

10. Rolffs, P.; Ockwell, D.; Byrne, R. Beyond technology and finance: Pay-as-you-go sustainable energy access and theories of social change. Environ. Plan 2015, 47, 2609-2627. [CrossRef]

11. ESMAP. Beyond Connections Energy Access Redefined: Conceptualization Report; The World Bank Group: Washington, DC, USA, 2015.

12. IRENA. International Renewable Energy Agency: Measurement and Estimation of Off-Grid Solar; Hydro and Biogas Energy: Abu Dhabi, United Arab Emirates, 2019.

13. Pedersen, M.B. Deconstructing the concept of renewable energy-based mini-grids for rural electrification in East Africa. Wires Energy Environ. 2016, 5, 570-587. [CrossRef]

14. Bhattacharyya, S.C.; Palit, D. The Nexus of Grids, Mini-Grids and Off-Grid Options for Expanding Electricity Access. Knowledge Paper. Applied Research Programme on Energy and Economic Growth; Oxford Policy Management: Oxford, UK, 2019.

15. Bastholm, C.; Fiedler, F. Techno-economic study of the impact of blackouts on the viability of connecting and off-grid PV-diesel hybrid system in Tanzania to the national power grid. Energy Convers. Manag. 2018, 171, 647-658. [CrossRef]

16. Adesanya, A.A.; Pearce, J.M. Economic viability of captive off-grid solar photovoltaic and diesel hybrid energy systems for the Nigerian private sector. Renew. Sustain. Energy Rev. 2019, 114, 109348. [CrossRef]

17. Johannsen, R.M.; Ostergaard, P.A.; Hanlin, R. Hybrid photovoltaic and wind mini-grids in Kenya: Techno-economic assessment and barriers to diffusion. Energy Sustain. Dev. 2020, 54, 111-126. [CrossRef]

18. Boamah, F.; Rothfub, E. From technical innovations towards social practices and socio-technical transition? Re-thinking the transition to decrentralised solar PV electrification in Africa. Energy Res. Soc. Sci. 2018, 42, 1-10. [CrossRef]

19. European Commission. The Green New Deal Project. 2020. Available online: https://ec.europa.eu/info/strategy/priorities-2019-2 024/ european-green-deal (accessed on 22 January 2021)

20. IEA. International Energy Agency. SDG7: Data and Projections. 2019. Available online: https://www.iea.org/reports/sdg7-dataand-projections / access-to-electricity (accessed on 22 January 2021)

21. Adeoye, O.; Spataru, C. Quantifying the integration of renewable energy sources in West Africa's interconnected electricity network. Renew. Sustain. Energy Rev. 2020, 120, 109647. [CrossRef]

22. Trimble, C.; Kojimalnes, M.; Perez Arroyo, I.; Mohammadzadeh, F. Financial Viability of Electricity Sectors in Sub-Saharan Africa. Quasi-Fiscal Deficits and Hidden Costs; The World Bank Group: Washington, DC, USA, 2016.

23. AFDBG, ERERA. Comparative Analysis of Electricity Tariffs in ECOWAS Member Countries. 2019. Available online: https://africa-e nergy-portal.org/reports/comparative-analysis-electricity-tariffs-ecowas-member-countries (accessed on 22 January 2021)

24. ECREEE. ECOWAS regional progress report on renewable energy, energy efficiency and energy access in ECOWAS region. 2017. Available online: http:/ / www.ecreee.org/sites/default/files/regional_progress_report_2017.pdf (accessed on 15 December 2020)

25. The World Bank. World Development Indicators. 2021. Available online: https://databank.worldbank.org/reports.aspx?source $=2 \&$ series $=$ EG.ELC.LOSS.ZS\&country $=($ accessed on 22 January 2021)

26. WAPP. Update of the ECOWAS Revised Master Plan for the Generation and Transmission of Electrical Energy: Final Report Volume 1: Study Data. 2021. Available online: http://www.ecowapp.org/sites/default/files/mp_wapp_volume_1.pdf (accessed on 15 December 2020).

27. WAPP. West African Power Pool. 2016-2019 WAPP Business Plan 2015; 2015. Available online: http://www.ecowapp.org/sites/ default/files/2015-2019_business_plan.pdf (accessed on 15 December 2020).

28. ECREEE. Country Data Profiles. 2020. Available online: http://www.ecowrex.org/page/country-profiles (accessed on 15 December 2020).

29. Pedersen, M.B.; Nygaard, I. System building in the Kenyan electrification regime: The case of private solar mini-grid development. Energy Res. Soc. Sci. 2018, 42, 211-223. [CrossRef]

30. ROGEP. Regional Off-Grid Electrification Project; 2020. Available online: http://www.ecreee.org/page/rogep-regional-off-grid -electrification-project (accessed on 15 December 2020).

31. Climatescope. 4Q 2019 Off-Grid and Mini-Grid Market Outlook. Bloomberg. 2019. Available online: http:/ / global-climatescope. org/library/off-grid/4q-2019 (accessed on 22 January 2021) 
32. Afrik21. MALI: Amader Launches Tender for Two Solar Power Plants of 2.6 MW; 2019. Available online: https:/ /www.afrik21.af $\mathrm{rica} / \mathrm{en} / \mathrm{mali}$-amader-launches-tender-for-two-solar-power-plants-of-2-6-mw/ (accessed on 15 December 2020).

33. ADBG. Burkina Faso Desert to Power Initiative-Yeleen Rural Electrification Project; 2018. Available online: https: //www.afdb.org/fileadmin/uploads/afdb/Documents /Project-and-Operations/Burkina_Faso_Desert_to_Power_Initi ative_Yeleen_Rural_Electrification_Project.pdf (accessed on 15 December 2020).

34. GCF. GCF Brings Clean Energy to Off-Grid Areas of Burkina Faso. 2018. Available online: https://www.greenclimate.fund/ne ws /gcf-brings-clean-energy-to-off-grid-areas-of-burkina-faso (accessed on 15 December 2020).

35. AT2ER. Rural Electrification Project of 317 Localities by Solar Mini-Grids in Togo; DAOI 001/AT2ER. 2019. Available online: https://ww w.togofirst.com/en/energy/1510-4152-togo-a-total-of-317-communities-will-have-access-to-light-using-solar-mini-grids (accessed on 15 December 2020).

36. Micro Grid Knowledge. World Bank Looks Forward to Nigerian Minigrid Boom; 2019. Available online: https: / / microgridkno wledge.com/nigeria-minigrid/ (accessed on 15 December 2020).

37. REA. Nigerian Mini Grid Tender. 2019. Available online: https://rea.gov.ng/mini-grid-tender/ (accessed on 15 December 2020).

38. Auth, K.; Musolino, E.; Tristram, T.; Adeola, A.; Reiss, K.; Semedo, E.; Williamson, L.; Chawla, K.; Diarra, C. ECOWAS Renewable Energy and Energy Efficiency Status Report-2014 (INIS-FR-15-0642). Available online: https://inis.iaea.org/search/search.aspx?o rig_q=RN:46105559 (accessed on 15 December 2020)

39. Sneij, J.; Hamid, M.M.; Mohamudally, N.; Abdulrahman, J.; Kappiah, M.; Emtairah, T. Experience in implementing multi-country energy information systems in West Africa and MENA regions. In Proceedings of the 2014 IST-Africa Conference Proceedings, Pointe aux Biches, Mauritius, 6-9 May 2014; pp. 1-11.

40. ECOWREX. ECOWAS Observatory for Renewable Energy and Energy Efficiency (ECOWREX). 2012. Available online: http: //www.ecowrex.org/ (accessed on 15 December 2020).

41. Szabo, S.; Bodis, K.; Huld, T.; Moner-Girona, M. Energy solutions in rural Africa: mapping electrification costs of distributed solar and diesel generation versus grid extension. Environ. Res. Lett. 2011, 6, 34002. [CrossRef]

42. Huld, T. Modeling the performance of simple off-grid PV systems. In Proceedings of the 27th 2012 European Photovoltaic Solar Energy Conference and Exhibition, Frankfurt, Germany, 24-28 September 2012.

43. Huld, T.; Moner-Girona, M.; Kriston, A. Geospatial analysis of photovoltaic mini-grid system performance. Energies 2017, 10, 218. [CrossRef]

44. Cader, C.; Bertheau, P.; Blechinger, P.; Huyskens, H.; Breyer, C. Global cost advantages of autonomous solar-battery-diesel systems compared to diesel-only systems. Energy Sustain. Dev. 2016, 31, 14-23. [CrossRef]

45. Moner-Girona, M.; Puig, D.; Mulugetta, Y.; Kougias, I.; Rahman, J.A.; Szabo, S. Next generation interactive tool as a backbone for universal access to electricity. Wires Energy Environ. 2018, 7, e305. [CrossRef]

46. Li, X.; Salasovich, J.; Reber, T. Microgrid Load and LCOE Modelling Results. National Renewable Energy Laboratory. 2018. Available online: https:/ / data.nrel.gov/submissions/79 (accessed on 15 December 2020).

47. GEP. Global Electrification Platform. 2020. Available online: https:/ / electrifynow.energydata.info/ (accessed on 15 December 2020).

48. EnergyDataInfo. Offgrid Market Opportunity Tool. 2020. Available online: http://offgrid.energydata.info/ (accessed on 15 December 2020).

49. IED. Systeme D'information Geographique sur L'etat et la Projection de L'electrification Rurale au Burkina Faso. 2006. Available online: https: / / www.improves-re.com/sig/ (accessed on 15 December 2020).

50. Moner-Girona, M.; Bodis, K.; Huld, T.; Kougias, I.; Szabo, S. Universal access to electricity in Burkina Faso: Scaling-up renewable energy technologies. Environ. Res. Lett. 2016, 11, 084010. [CrossRef]

51. Moner-Girona, M.; Bodis, K.; Korgo, B.; Huld, T.; Kougias, I.; Pinedo-Pascua, I.; Monforti-Ferrario, F.; Szabo, S. Mapping the Least-Cost Option for Rural Electrification in Burkina Faso; JRC Science for Policy Report; JRC: Luxembourg, 2017.

52. Diouf, B.; Pode, R.; Osei, R. Initiative for $100 \%$ rural electrification in developing countries: Case study of Senegal. Energy Policy 2013, 926-930. [CrossRef]

53. Koua, K.; Magloire, P.; Koffi, E.; Gbaha, P.; Toure, S. Present status and overview of potential of renewable energy in Cote d'Ivoire. Renew. Sustain. Energy Rev. 2015, 41, 907-914. [CrossRef]

54. Sawadogo, W.; Abiodun, B.J.; Okogbue, E.C. Impacts of Global Warming on Photovoltaic Power Generation over West Africa. 2020. https://ideas.repec.org/a/eee/renene/v151y2020icp263-277.html (accessed on 15 December 2020).

55. Obeng, G.Y.; Evers, H.-D.; Akuffo, F.O.; Braimah, I.; Brew-Hammond, A. Solar photovoltaic electrification and rural energypoverty in Ghana. Energy Sustain. Dev. 2008, 12, 43-54. [CrossRef]

56. Adusah-Poku, F.; Takeuchi, K. Energy poverty in Ghana: any progress so far? Renew. Sustain. Energy Rev. 2019, 112, 853-864. [CrossRef]

57. Adusah-Poku, F.; Takeuchi, K. Determinants and welfare impacts of rural electrification in Ghana. Energy Sustain. Dev. 2019, 52, 52-62. [CrossRef]

58. Lin, B.; Ankrah, I. Renewable energy (electricity) development in Ghana: observations, concerns, substitution possibilities, and implication for the economy. J. Clean. Prod. 2019, 233, 1396-1409. [CrossRef] 
59. UNF, SE4ALL. Lasting Impact Sustainable Off-Grid Solar Delivery Models to Power Health and Education; United Nation Foundation and SE4ALL Report. 2019. Available online: https:/ /www.seforall.org/publications/lasting-impact-sustainable-off-grid-solar-d elivery-models (accessed on 15 December 2020)

60. Marong, L.K.; Jirakiattikul, S.; Techato, K. The Gambia's future electricity supply system: optimizing power supply for sustainable development. Energy Strat. Rev. 2018, 20, 179-194. [CrossRef]

61. Maji, I.K.; Sulaiman, C.; Abdul-Rahim, A.S. Renewable energy consumption and economic growth nexus: a fresh evidence from West Africa. Energy Rep. 2019, 5, 384-392. [CrossRef]

62. SE4ALL. Green Mini-Grids Are a Key Strategy for Achieving Universal Power Access in Africa. 2020. Available online: https:/ / www.se4all-africa.org/seforall-in-africa/regional-initiatives/green-mini-grids/ (accessed on 15 December 2020).

63. Booth, S.; Li, X.; Baring-Gould, I.; Kollanyi, D.; Bharadwaj, A.; Weston, P. Productive Use of Energy in African Micro-Grids: Technical and Business Considerations. USAID \& NREL Report. 2018. Available online: https:/ / energy4impact.org/productive -use-energy-african-micro-grids-technical-and-business-considerations-0 (accessed on 15 December 2020).

64. Atuguba, R.A.; Tuokuu, F.X.D. Ghana's renewable energy agenda: Legislative drafting in search of policy paralysis. Energy Res. Soc. Sci. 2020, 64, 101453. [CrossRef]

65. Obeng-Darko, N.A. Why Ghana will not achieve its renewable energy target for electricity. Policy, legal and regulatory implications. Energy Policy 2019, 128, 75-83. [CrossRef]

66. Sakah, M.M.; Felix, A.D.; Rolf, K.; Gyamfi, S. Towards a sustainable electrification in Ghana: A review of renewable energy deployment policies. Renew. Sustain. Energy Rev. 2017, 79, 544-557. [CrossRef]

67. Pueyo, A. What Constrains Renewable Energy Investment in Sub-Saharan Africa? A Comparison of Kenya and Ghana. World Dev. 2018, 109, 85-100. [CrossRef]

68. Moner-Girona, M.; Solano-Peralta, M.; Lazopoulou, M.; Ackom, E.K.; Vallve, X.; Szabo, S. Electrification of Sub-Saharan Africa through PV/hybrid mini-grids: Reducing the gap between current business models and on-site experience. Renew. Sustain. Energy Rev. 2018, 91, 1148-1161. [CrossRef]

69. Quansah, D.A.; Adaramola, M.S.; Mensah, L.D. Solar photovoltaics in sus-Saharan Africa-addressing barriers, unlocking potential. Energy Procedia 2016, 106, 97-110. [CrossRef]

70. Ockwell, D.; Byrne, R.; Hansen, U.E.; Haselip, J.; Nygaard, I. The uptake and diffusion of solar power in Africa: Socio-cultural and political insights on a rapidly emerging socio-technical transition. Energy Res. Soc. Sci. 2018, 44, 122-129. [CrossRef]

71. USAID. Power Africa. Off-Grid Solar Market Assessment Ghana. 2019. Available online: https://www.usaid.gov/powerafrica/be yondthegrid/ off-grid-solar-assessment/ghana (accessed on 15 December 2020).

72. USAID. Power Africa. Off-Grid Solar Market Assessment Senegal. 2019. Available online: https://www.usaid.gov/powerafrica/be yondthegrid/off-grid-solar-assessment/senegal (accessed on 15 December 2020).

73. USAID. Power Africa. Off-Grid Solar Market Assessment Cote D'Ivoire. 2019. Available online: https://www.usaid.gov / powerafric a/beyondthegrid/off-grid-solar-assessment/cote-divoire (accessed on 15 December 2020).

74. USAID. Power Africa. Off-Grid Solar Market Assessment Niger. 2019. Available online: https://www.usaid.gov/powerafrica/beyo ndthegrid/off-grid-solar-assessment/niger (accessed on 15 December 2020).

75. RMI. Minigrid Investment Report. Scaling the Nigerian Market; Rocky Mountain Institute: Abuja, Nigeria. 2018.

76. USAID. African Union, Power Africa. Exploring Africa's Mini-Grid Tariff Methodologies. 2020. Available online: https: //www.naruc.org/international/news/exploring-africa-s-mini-grid-tariff-methodologies/ (accessed on 15 December 2020).

77. REA. The Rural Electrification Agency-Solar Hybrid Mini Grids. 2021. Available online: https://rea.gov.ng/minigrids/ (accessed on 1 January 2021).

78. RECP; EUEI PDF; ARE; REN21. Mini-Grid Policy Toolkit. Policy and Business Frameworks for Successful Mini-Grid Roll-Outs; 2014. Available online: http:/ / minigridpolicytoolkit.euei-pdf.org/ (accessed on 15 December 2020).

79. AFBD. The Mini Grid Help Desk. 2021. Available online: https://greenminigrid.afdb.org/country/cape-verde (accessed on 22 January 2021).

80. Alfaro, J.; Miller, S. Satisfying the rural residential demand in Liberia with decentralized renewable energy schemes. Renew. Sustain. Energy Rev. 2014, 30, 903-911. [CrossRef]

81. Thiam, D.R. Renewable decentralized in developing countries: Appraisal from microgrids. Renew. Energy 2010, 35, 1615-1623. [CrossRef]

82. Obeng, G.Y.; Evers, H.D. Impacts of public solar PV electrification on rural micro-enterprises: The case of Ghana. Energy Sustain. Dev. 2010, 14, 223-231. [CrossRef]

83. Odou, O.D.T.; Bhandari, R.; Adamou, R. Hybrid off-grid renewable power system for sustainable rural electrification in Benin. Renew. Energy 2020, 145, 1266-1279. [CrossRef]

84. Williams, N.; Booth, S.; Baring-Gould, I. Survey Use in Micro-Grid Load Prediction, Project Development and Operations. NREL and USAID Report. 2019. Available online: https://www.climatelinks.org/resources/survey-use-micro-grid-load-prediction-p roject-development-and-operations-review-and-best (accessed on 15 December 2020).

85. RMI. Under the Grid, RMI Report. 2018. Available online: https://rmi.org/wp-content/uploads/2018/11/rmi-undergrid-repor t.pdf (accessed on 15 December 2020).

86. Plain, N.; Hingray, B.; Mathy, S. Accounting for low solar resource days to size $100 \%$ solar microgrids power systems in Africa. Renew. Energy 2019, 131, 448-458. [CrossRef] 
87. Diouf, B.; Avis, C. The potential of Li-ion batteries in ECOWAS solar home systems. J. Energy Storage 2019, 22, 295-301. [CrossRef]

88. Quansah, D.A.; Adaramola, M.S. Ageing and degradation in solar photovoltaic modules installed in northern Ghana. Sol. Energy 2018, 173, 834-847. [CrossRef]

89. Mensah, L.D.; Yamoah, J.O.; Adaramola, M.S. Performance evaluation of a utility-scale grid-tied solar photovoltaic (PV) installation in Ghana. Energy Sustain. Dev. 2019, 48, 82-87. [CrossRef]

90. Konneh, D.A; Lofty, M.E.; Shigenobu, R.; Senjyu, T. Optimal Sizing of Grid-Connected Renewable Energy System in Freetown Sierra Leone. IFAC PapersOnLine. 2018. Available online: https://www.sciencedirect.com/science/article/pii/S2405896318334 190 (accessed on 15 December 2020).

91. Adeoye, O.; Spataru, C. Sustainable development of the West African Power Pool: Increasing solar energy integration and regional electricity trade. Energy Sustain. Dev. 2018, 45, 124-134. [CrossRef]

92. Trotter, P.A.; Maconachie, R.; McManus, M.C. Solar energy's potential to mitigate political risks: The case of an optimized Africa-wide network. Energy Policy 2018, 117, 108-126. [CrossRef]

93. World Bank. 2019 Climate Investment Funds-Clean Technology Fund (CTF) Results Data. 2019. Available online: https:/ finan ces.worldbank.org/Projects/2019-Climate-Investment-Funds-Clean-Technology-Fun/kjmm-jfbk (accessed on 15 December 2020).

94. SEforALL. State of the Global Mini-Grids Market Report 2020. Sustainable Energy for All report. 2020. Available online: https:/ / www.seforall.org/publications/state-of-the-global-mini-grids-market-report-2020 (accessed on 15 December 2020).

95. ESMAP. Mini Grid Costing and Innovation. Mini Grids for Half a Billion Poeple. 2019. Available online: https://www.worldbank.or g/en/topic/energy/publication/mini-grids-for-half-a-billion-people (accessed on 15 December 2020).

96. AMMP. Reducing the Cost of Operations and Maintenance for Remote Off-Grid Energy Systems. The Impact of Remote Monitoring. 2018. Available online: https://www.ammp.io/remote-monitoring-cost-reduction/ (accessed on 15 December 2020).

97. Ulsrud, K.; Muchunku, C.; Palit, D.; Kirubi, G. Solar Energy, Mini-Grids and Sustainable Electricity Access-Practical Experiences, Lessons and Solutions from Senegal (1); Routledge: London, UK, 2018; 126p, ISBN 978113835903. Available online: https: / / www.routledge.com/Solar-Energy-Mini-grids-and-Sustainable-Electricity-Access-Practical-Experiences/Ulsrud-Mu chunku-Palit-Kirubi/p/book/9780367606701 (accessed on 15 December 2020).

98. Ulsrud, K.; Rohracher, H.; Winther, T.; Muchunku, C.; Palit, D. Pathways to electricity for all: What makes village-scale solar power successful? Energy Res. Soc. Sci. 2018, 44, 32-40. [CrossRef]

99. Draeck, M.; Kottasz, E. Renewable Energy-Based Mini-Grids: The UNIDO Experience; United Nations Industrial Development Organization: Vienna, Austria, 2017. Available online: https://www.unido.org/sites/default/files/2017-03/Minigrid_report_J an2017.v19_FINAL29906_0.pdf (accessed on 15 December 2020).

100. Energy Action Partners. The Minigrid Game. 2017. Available online: https://www.theminigridgame.org/ (accessed on 15 December 2020).

101. Relancio, J. Telephonic interview with Javier Relancio, Off-Grid Expert and Business Developer Manager at Mott MacDonald (2019, February); 2019.

102. Brosz, C. Telephonic interview with Chris Brosz, Mini Grid Consultant at UNOPS (2020, March 20); 2020.

103. Akella, A.K.; Saini, R.P.; Sharma, M.P. Social, economical and environmental impacts of renewable energy systems. Renew. Energy 2009, 34, 390-396. [CrossRef]

104. Galindez, A. Telephonic Interview with Angel Galindez, Off-Grid Electrification Consultant at Fundacion EKI. 16 March 2020.

105. Wang, R.; Lam, C.-M.; Hsu, S.-C.; Chen, J.-H. Life cycle assessment and energy payback time of a standalone hybrid renewable energy commercial microgrid: A case study of Town Island in Hong Kong. Appl. Energy 2019, 250, 760-775. [CrossRef]

106. USAID. What Environmental, Health and Safety Impacts Can a Mini-Grid Have? 2020. Available online: https://www.usaid.go v/energy/mini-grids/environment-health-safety/impacts (accessed on 15 December 2020).

107. GIZ. End-of-Life Management of Batteries in the Off-Grid Solar Sector. A Deutsche Gesellschaft für Internationale Zusammenarbeit (GIZ) GmbH Report; 2018. Available online: https://energypedia.info/wiki/End-of-Life_Management_of_Batteries_in_the_Off-Grid_S olar_Sector (accessed on 15 December 2020).

108. Diouf, N.T.; Charif, A.B.; Adisso, L.; Adepkedjou, R.; Zomahun, H.T.V.; Agbadje, T.T.; Dogbaade, M.J.; Garvelink, M.M. Shared decision making in West Africa: The forgotten area. Zeitschrift für Evidenz, Fortbildung und Qualität im Gesundheitswesen. 2017; pp. 123-124. Available online: https:/ / pubmed.ncbi.nlm.nih.gov/28527636/ (accessed on 15 December 2020).

109. Monyei, C.; Adewumi, A.; Jenkins, K. Energy (in)justice in off-grid rural electrification policy: South Africa in focus. Energy Res. Soc. Sci. 2018, 44, 152-171. [CrossRef]

110. Bouzarovsky, S.; Simcock, N. Spatializing energy justice. Energy Policy 2017, 107, 640-648. [CrossRef]

111. Yenneti, K.; Day, R.; Golubchikov, O. Spatial justice and the land politics of renewables: Dispossessing vulnerable communities through solar energy megaprojects. Geoforum 2016, 76, 90-99. [CrossRef]

112. Ellegard, A.; Arvidson, A.; Nordström, M.; kalumiana, O.S.; Mwanza, C. Rural people pay for solar: Experiences from the Zambia PV-ESCO project. Renew. Energy 2004, 29, 1251-1263. [CrossRef]

113. Azimoh, C.; Klintenberg, P.; Wallin, F.; Karlsson, B. Illuminated but not electrified: An assessment of the impact of Solar Home System on rural households in South Africa. Appl. Energy 2015, 155, 354-364. [CrossRef]

114. Alcott, B. Jevon's paradox. Ecol. Econ. 2005, 54, 9-21. [CrossRef] 
115. Roy, J. The rebound effect: Some empirical evidence from India. Energy Policy 2000, 28, 433-438. [CrossRef]

116. Agenbroad, J.; Carlin, K.; Ernst, K.; Doig, S. Minigrids in the Money. Six Ways to Reduce Mini Grid Costs by $60 \%$ for Rural Electrification. Rocky Mountain Institute. 2018. Available online: https://rmi.org/wp-content/uploads/2018/12/rmi-seeds-m inigrid-report.pdf (accessed on 15 December 2020). 